\title{
The Ombudsman Enterprise and Administrative Justice
}

\author{
Trevor Buck, De Montfort University, UK, Richard Kirkham, \\ University of Sheffield, UK and Brian Thompson, University of \\ Liverpool, UK
}

'This is a timely and important book, providing insight and analysis of the ombudsman enterprise in the UK, and placing ombudsmen very clearly within the wider administrative justice system. It will have significant influence on policy and practice, and is a valuable contribution to the study of ombudsmen.'

- Mary Seneviratne, Nottingham Trent University, UK

'Scholarly and well-researched, offering an interesting blend of constitutional theory and well-chosen illustrative material, this is an important addition to the literature on administrative justice. It will surely be essential reading, not just for academics working in this field but also for established and developing ombudsman offices around the world.' - Gavin Drewry, University of London, UK

'This important new book presents an overview of one of the key institutions of administrative justice: the ombudsman. It presents a well argued thesis based on a thorough review of the literature and some new empirical research concerning the changing role of, and future prospects for, ombudsmen. It makes excellent use of international comparisons with a particular emphasis on Commonwealth experience. It will be invaluable to academics and policy-makers working in the field whilst also being accessible to students.'

- Tom Mullen, University of Glasgow, UK

The statutory duty of public service ombudsmen (PSO) is to investigate claims of injustice caused by maladministration in the provision of public services. This book examines the modern role of the ombudsman within the overall emerging system of administrative justice and makes recommendations as to how PSO should optimize their potential within the wider administrative justice context.
Contents: Foreword; Preface; Part I Theory and Context: The ombudsman enterprise: an introduction; The constitutional role of the ombudsman; Concepts, theories and policies of administrative justice. Part II The Ombudsman Technique: Putting it right: resolving complaints and assisting citizens; Promoting good administration and helping to get it right. Part III Setting It RIGHt: Independence and accountability: legitimising the ombudsman; Relationships, networks and the administrative justice system; PART IV CONCLUSION: The 21 st century ombudsman enterprise; Appendices; Bibliography; Index.

Sample pages for published titles are available to view online at: www.ashgate.com

To order, please visit: www.ashgate.com All online orders receive a discount

Alternatively, contact our distributor: Bookpoint Ltd, Ashgate Publishing Direct Sales, 130 Milton Park, Abingdon, Oxon, OX14 4SB, UK Tel: +44 (0)1235 827730 Fax: +44 (0)1235 400454

Email: ashgate@bookpoint.co.uk

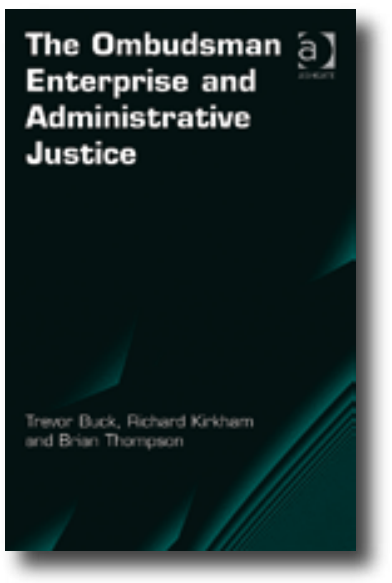

The Ombudsman á) Enterprise and Administrative Justice
December 2010

308 pages

Hardback

978-0-7546-7556-3

$£ 70.00$

This title is also available

as an ebook

978-1-4094-2015-6 